\title{
Characterization of apoptotic changes induced by yessotoxin in the Bel7402 human hepatoma cell line
}

\author{
MIN PANG, ZONG-LING WANG, CHUN-LEI GAO, PEI QU and HAI-DONG LI \\ The First Institute of Oceanography, State Oceanic Administration, Qingdao, Shandong 266061, P.R. China
}

Received October 19, 2010; Accepted February 24, 2011

DOI: $10.3892 / \mathrm{mmr} .2011 .452$

\begin{abstract}
The apoptotic effects of yessotoxin (YTX) on Bel7402 human hepatoma cells have been evaluated by the combination of several methods, including optical microscopy, Hoechst 33342 staining and DNA gel electrophoresis. Rhodamine 123 staining has also been used to investigate changes in mitochondrial transmembrane potential. The results indicated that YTX has negative effects on human liver cells and induces apoptosis. Furthermore, changes in calcium concentrations were analyzed using the fluorescence probe Fluo-3 AM. The results showed that intracellular calcium concentrations increased after treatment with YTX.
\end{abstract}

\section{Introduction}

Yessotoxin (YTX) is a disulfated polyether lipophilic marine toxin. Since YTX and its analogues are always detected together with diarrhoeic shellfish poisoning (DSP) toxins such as okadaic acid (OA), they were for a long time classified in the DSP toxin group. However, YTX does not induce diarrhea nor does it inhibit protein phosphatases, as do DSP toxins (1). Thus, in 2002 YTX was removed from the DSP toxin group by the European Union Commission and classified as an independent marine toxin (2).

YTX and its analogues were first isolated from the digestive organs of the scallop Patinopecten yessoensis in

Correspondence to: Dr Zong-Ling Wang, The First Institute of Oceanography, State Oceanic Administration, Qingdao, Shandong 266061, P.R. China

E-mail: wangzl@fio.org.cn

Abbreviations: AM, acetoxymethyl ester; DMSO, dimethyl sulphoxide; DSP, diarrheic shellfish poisoning; FCS, fetal calf serum; MTP, mitochondria transmembrane potential; MTT, 3-(4,5dimethylthiazol-2-yl)-2,5-diphenyltetrazolium bromide; NRC, National Research Council; OA, okadaic acid; PBS, phosphatebuffered saline; PI, propidium iodide; Rh123, rhodamine 123; RNaseA, ribonuclease A; YTX, yessotoxin

Key words: yessotoxin, apoptosis, Bel7402 hepatoma cell line, mitochondria transmembrane potential, $\mathrm{Ca}^{2+}$
Japan (3), and are mainly produced by the algae dinoflagellates Protoceratium reticulatum, Gonyaulax spinifera and Lingulodinium polyedrum $(4,5)$. These three species have been identified in numerous European and American countries (4,6-10), and their cysts have recently been identified in the silt of the Yellow Sea (11). In 2009, Gao et al deteceted YTX and its analogues in shellfish samples collected from several coastal cities in China (12). Therefore, the YTX family is of concern in seafood quality monitoring and the shellfish industry.

Although the mechanisms of YTX toxicity have been investigated for years, its exact mechanisms remain unknown. Since the chemical structure of YTX is similar to that of brevetoxin, which is known as a neurotoxin, the interaction between YTX and cellular ion channels has been studied (13). Cellular ion levels are important in the regulation of cellular biological functions. YTX has been identified as an inducer of apoptosis in the neuroblastoma cell line BE (2)-M17 (14) and the human cervical cancer cell line Hela (15). It has also been reported that YTX induces apoptotic events in myoblast cell lines from rats and mice (16).

Apoptosis plays a key role in the pathogenesis of disease, including cancer (17-19). Apoptosis is a normal element of the growth and health of multicellular organisms, and plays an essential role throughout the regulation of tissue development and homeostasis $(17,20,21)$. Cancer is mainly caused by the disruption of cellular homeostasis between cell death and proliferation (22). Studying the induction of apoptosis may aid in the identification of effective cancer therapies.

Apoptotic cells have characteristic features, including chromatin aggregation, nuclear and cytoplasmic condensation, nuclear fragmentation and the partition of protuberances that form on the cell surface (23). It is necessary to combine different parameters and several biochemical markers identified in the process of apoptosis, including the decrease of mitochondrial transmembrane potential (MTP), DNA fragmentation and the activation of caspases, to detect apoptosis in most apoptotic cells. In this study, the human hepatoma cell line Bel7402 was used to study the sensitivity and the toxicity of YTX. The cytotoxicity and cell death induced by YTX in hepatoma cells was evaluated and various apoptotic-related features were analyzed to address the apoptotic pathway activated in Bel7402 cells treated with YTX. The results indicate that YTX may have anticancer activity against human liver cancer via the induction of apoptosis. 


\section{Materials and methods}

Chemicals and solutions. YTX and OA were purchased from the National Research Council (NRC; Canada) and were dissolved in phosphate buffer to a final concentration of $2 \mathrm{ng} /$ $\mu 1$ for the experiments. The fluorescence probes Hoechst 33342 and propidium iodide (PI) were included in an apoptosis and necrosis assay purchased from the Beyotime Insititute of Biotechnology (Shanghai, China). Rhodamine 123 (Rh123) and Fluo-3 acetoxymethyl ester (AM) solution with a concentration of $5 \mathrm{mM}$ were also purchased from Beyotime. 3-(4,5)-dimethylthiahiazo-2-y1)-3, 5-diphenyltetrazolium bromide (MTT) was from Sigma (St. Louis, MO, USA).

Cell culture and treatment. The Bel7402 human hepatoma cell line was purchased from the cell bank of the Shanghai Institute of Biochemistry and Cell Biology, Chinese Academy of Sciences (Shanghai, China). The cells were seeded in $25-\mathrm{cm}^{2}$ flasks at a density of $1 \times 10^{4}$ cells/ml and cultured in RPMI-1640 (Gibco, USA) with $300 \mathrm{mg} / \mathrm{l}$ L-Glutamine, $100 \mathrm{U} / \mathrm{ml}$ penicillin, $100 \mu \mathrm{g} / \mathrm{ml}$ streptomycin and $15 \%$ fetal calf serum (FCS; TBD, China). The cells were maintained at $37^{\circ} \mathrm{C}$ until $80-90 \%$ confluence was reached.

Antiproliferative activity measurement. The proliferative activities of the cells were measured by the MTT assay, since MTT converts formazan crystals by mitochondrial dehydrogenases (24). For microplate assays, the split cells were trypsinized after reaching optimum confluence, and the concentration of the culture was adjusted to $1 \times 10^{4}$ cells $/ \mathrm{ml}$. Following an additional incubation of $24 \mathrm{~h}$ at $37^{\circ} \mathrm{C}$, cells grown in 96-well microplates were used for the MTT assay. OA and YTX were added in serial concentrations $(50-300 \mathrm{ng} / \mathrm{ml})$. PBS alone was added as the control and all groups were re-incubated for 20 h. Then, $20 \mu 1$ of $2 \mathrm{mg} / \mathrm{ml}$ MTT solution was added to the medium and the incubation was continued for $4 \mathrm{~h}$ at $37^{\circ} \mathrm{C}$. After the removal of the medium, $150 \mu 1$ DMSO was added to each well to dissolve the formazan and the absorbance at $490 \mathrm{~nm}$ was read on a microplate reader (Rayto, China). The inhibition ratio $(\%)$ of toxins was calculated by the equation: inhibition ratio $(\%)=\left(1-\mathrm{A}_{\text {treatmenl }} / \mathrm{A}_{\text {control }}\right) \times 100 \%$.

Observation of morphological changes. After incubation with $50 \mathrm{ng} / \mathrm{ml}$ of OA or YTX for $48 \mathrm{~h}$, morphological changes in the Bel7402 cells were observed under an optical microscope. Furthermore, Hoechst 33342 fluorescent dye was used to observe changes in the cell nuclei when the cells were treated with the toxins for $24 \mathrm{~h}$. Then, the medium was removed, the treated cells were resuspended in staining buffer and stained with Hoechst 33342 for $30 \mathrm{~min}$ at $4^{\circ} \mathrm{C}$. After washing with phosphate-buffered saline (PBS), the nuclei were observed using a fluorescence microscope (Nikon, Japan) under UV light.

DNA fragmentation by agarose gel electrophoresis. Compared to the untreated control group, Bel7402 cells were incubated in medium containing $50 \mathrm{ng} / \mathrm{ml}$ OA or YTX for $48 \mathrm{~h}$. Then, the cell cultures were collected, washed in PBS and resuspended in $50 \mu 1$ lysis buffer. After treatment with $10 \mu 1$ RnaseA $(1 \mathrm{mg} /$ $\mathrm{ml})$ at $37^{\circ} \mathrm{C}$ for $1 \mathrm{~h}, 10 \mu 1$ proteinase $\mathrm{K}(20 \mathrm{mg} / \mathrm{ml})$ was added to the samples followed by incubation at $55^{\circ} \mathrm{C}$ for at least $3 \mathrm{~h}$.
After the addition of a 10X loading buffer, electrophoresis of the extracted DNA was carried out on $2.0 \%$ agarose gels. A 200-bp DNA marker was used to compare the size of the DNA fragments. DNA bands were visualized by ethidium bromide staining (Molecular Probes Inc.).

Measurement of caspase-3 activity. The activation of caspase- 3 was determined using a Caspase-3 assay (Beyotime Insititute of Biotechnology). After cleavage from the labeled substrate DEVD-pNA, the light emission of the chromophore p-nitroanilide (pNA) was quantified using a microplate reader at $405 \mathrm{~nm}$. Comparison of the pNA absorbance between an apoptotic sample and an untreated one was used to evaluate the activation of caspase- 3 in the cells.

Analysis of mitochondrial transmembrane potential. MTP was measured using the fluorescent probe Rh123. Before treatment, Rh123 was diluted in PBS to a final concentration of $10 \mathrm{mg} / \mathrm{l}$. Cells $\left(10^{6}\right)$ were collected after trypsinization and incubated with YTX or OA (50 ng/ml) for 2, 4, 6, 8, 10 or $12 \mathrm{~h}$. After being washed twice in PBS, the treated cells were re-incubated with $\mathrm{Rh} 123$ for $30 \mathrm{~min}$ at $37^{\circ} \mathrm{C}$ in the dark, and the samples were analyzed by flow cytometry (BD FACScanto $^{\mathrm{TM}}$, USA).

Analysis of intracellular calcium levels. After trypsinization, the collected Bel7402 cells were washed in PBS and loaded with the Fluo-3 AM fluorescent dye $(5 \mu \mathrm{mol} / \mathrm{l})$ for $1 \mathrm{~h}$ at $37^{\circ} \mathrm{C}$ in the dark. Then, the cells were washed again and incubated with the medium containing the toxins (OA or YTX, $50 \mathrm{ng} / \mathrm{ml}$ ) for 30 or $60 \mathrm{~min}$. The incubation was protected from light. Finally, the fluorescence intensity of intracellular calcium was measured using flow cytometry.

\section{Results}

Antiproliferative activity of $O A$ and YTX. The cytotoxic activity of the toxins was evaluated by the MTT assay. As shown in Fig. 1, the inhibition of Bel7402 cell proliferation by YTX occured in a dose-dependent manner, and the growth of the cells was also inhibited by OA. In order to visualize the apoptotic changes induced by YTX, a concentration of $50 \mathrm{ng} / \mathrm{ml}$ was selected for use in the following experiments.

Morphological changes. Observed under a microscope, cells in the control group grew well and the nuclei were round and clear. Morphological changes of apoptosis were observed in cells treated with $50 \mathrm{ng} / \mathrm{ml} \mathrm{OA}$ or YTX for $48 \mathrm{~h}$. Cells treated with YTX were misshapen and some were even broken. Nuclei were marginalized in some cells, indicated by arrows in Fig. 2.

After nuclear staining with Hoechst 33342, control group cells were observed to have regular and round-shaped nuclei under a fluorescence microscope. By contrast, cells treated with OA or YTX for $24 \mathrm{~h}$ presented typical features of early-stage apoptosis. Using Hoechst 33342 staining, nuclear condensation was identified as bright blue staining and apoptotic bodies were observed to have nuclear fragmentation (Fig. 3). The apoptotic cells and total cells in each field of view 


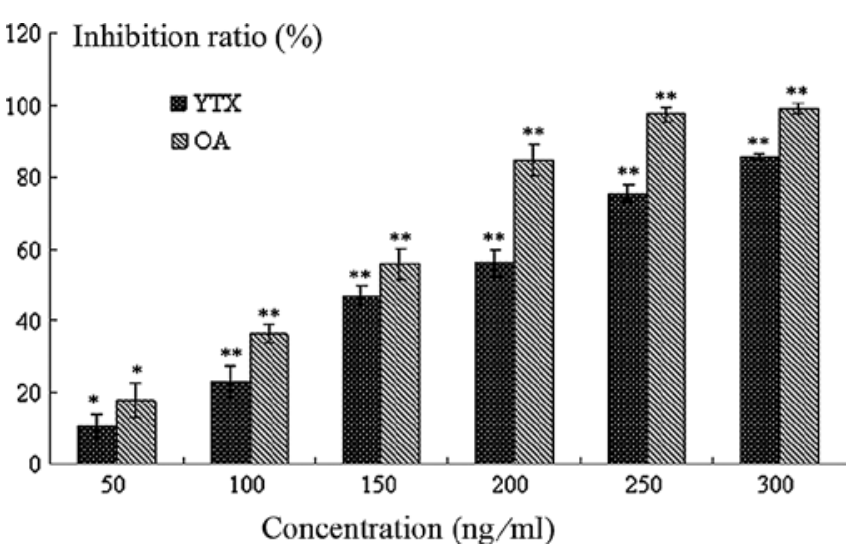

Figure 1. Inhibition of Bel7402 cell proliferation by OA and YTX at different concentrations. ${ }^{*} \mathrm{P}<0.05 ;{ }^{* *} \mathrm{P}<0.01$ with respect to the control.

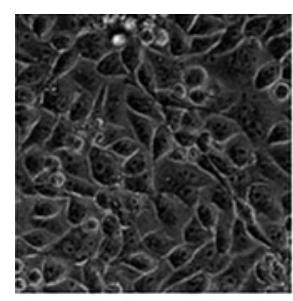

Control

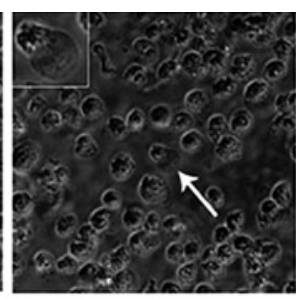

$\mathrm{OA}$

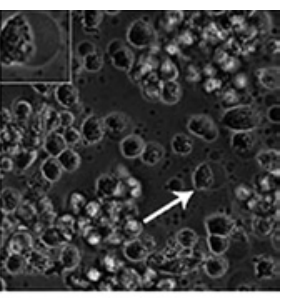

YTX
Figure 2. Morphological changes of Bel7402 cells treated with $50 \mathrm{ng} / \mathrm{ml} \mathrm{OA}$ and $50 \mathrm{ng} / \mathrm{ml}$ YTX for $48 \mathrm{~h}$ (x200). The cells indicated by arrows showed clear morphological changes associated with apoptosis.

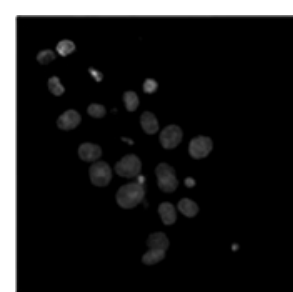

Control

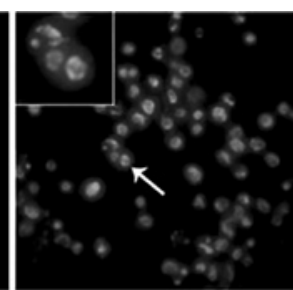

$\mathrm{OA}$

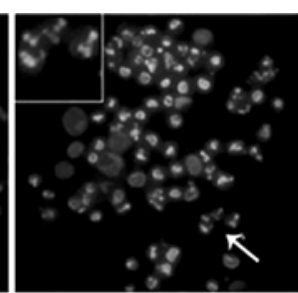

YTX
Figure 3. Changes to nuclei after Hoechst 33342 staining in the control cells and in the toxin-treated group (x200).

were counted, and the ratio of apoptotic cells was calculated (Fig. 4). The results showed that the apoptotic cells induced by YTX were slightly fewer than those induced by OA.

DNA fragmentation. After incubation with toxins for $48 \mathrm{~h}$, DNA fragmentation was evaluated by $2.0 \%$ agarose gel electrophoresis. DNA isolated from the control group remained totally intact and devoid of any fragmentation. Compared to a 200-bp DNA ladder marker, the overall pattern of DNA fragmentation and an clear ladder suggested the presence of massive cell apoptosis induced by OA or YTX (Fig. 5).

Effects of toxins on the activation of caspase-3. Since caspase plays a critical role in cell apoptosis, its activity was analyzed in this study. The results showed that caspase-3 activity was

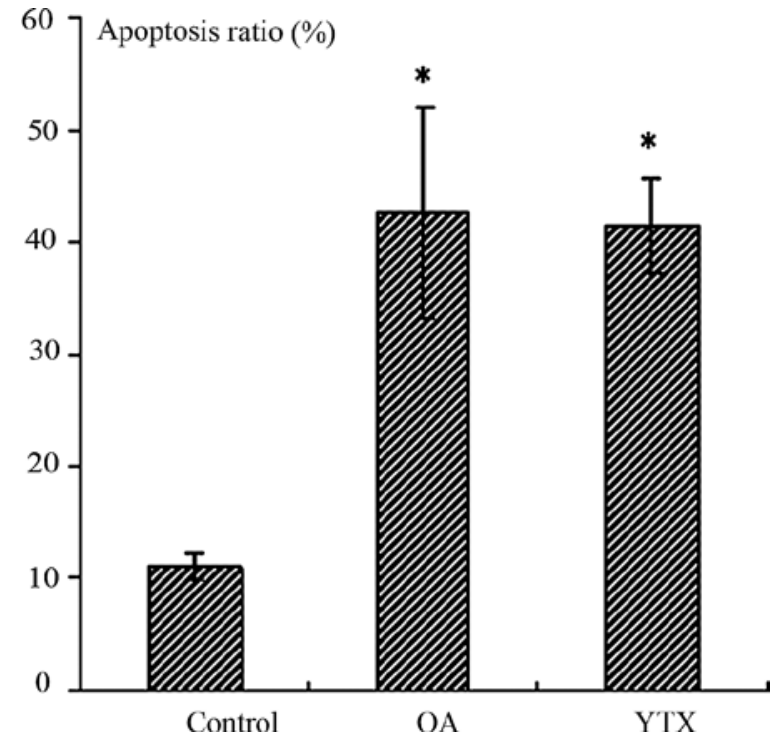

Figure 4. Ratio of apoptotic cells treated with $50 \mathrm{ng} / \mathrm{ml} \mathrm{OA}$ or $50 \mathrm{ng} / \mathrm{ml}$ YTX. " $\mathrm{P}<0.01$ with respect to control. As determined by Hoechst 33342 staining, the ratio of apoptosis was 42.59 and $41.55 \%$ after treatment with OA and YTX, respectively.

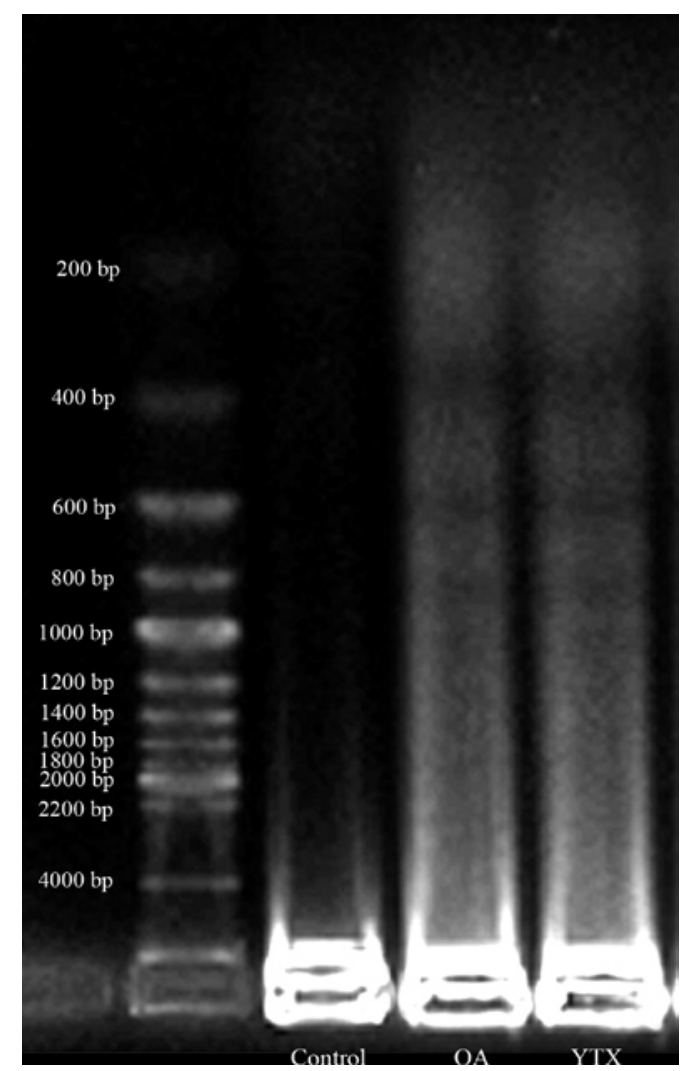

Figure 5. Electrophoretic results of DNA fragmentation from OA- and YTXtreated Bel7402 cells. Electrophoresis was carried out on $2.0 \%$ agarose gels.

increased more in the YTX-treated cells compared to the OA-treated cells or the control groups after $3 \mathrm{~h}$ of incubation. However, when incubated for $>6 \mathrm{~h}$, the caspase- 3 activity of cells treated by OA was enhanced to a greater extent compared to cells treated with YTX (Fig. 6). 


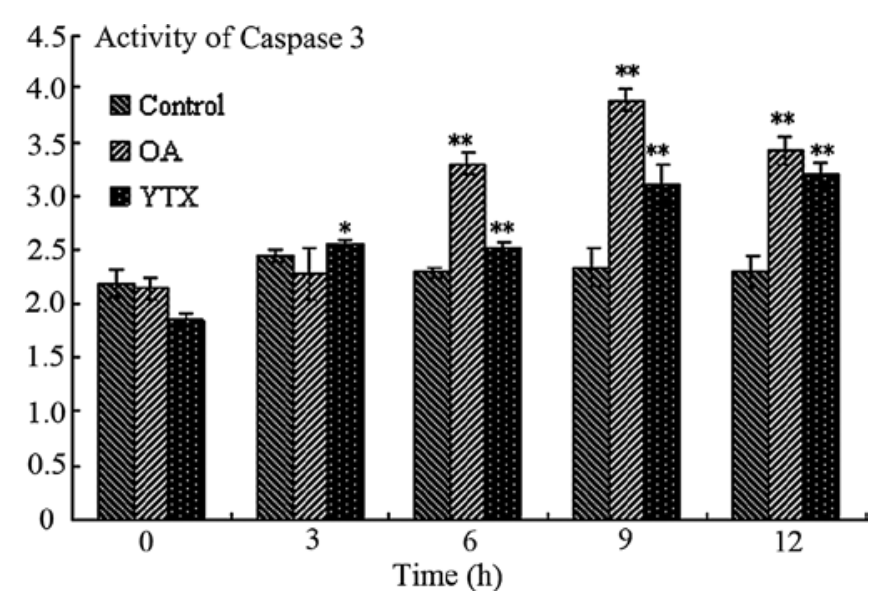

Figure 6. The activation of caspase-3 changed in Bel7402 cells treated with OA or YTX for $0-12 \mathrm{~h}$ as compared to the control group. ${ }^{*} \mathrm{P}<0.05 ;{ }^{* *} \mathrm{P}<0.01$ with respect to the control.

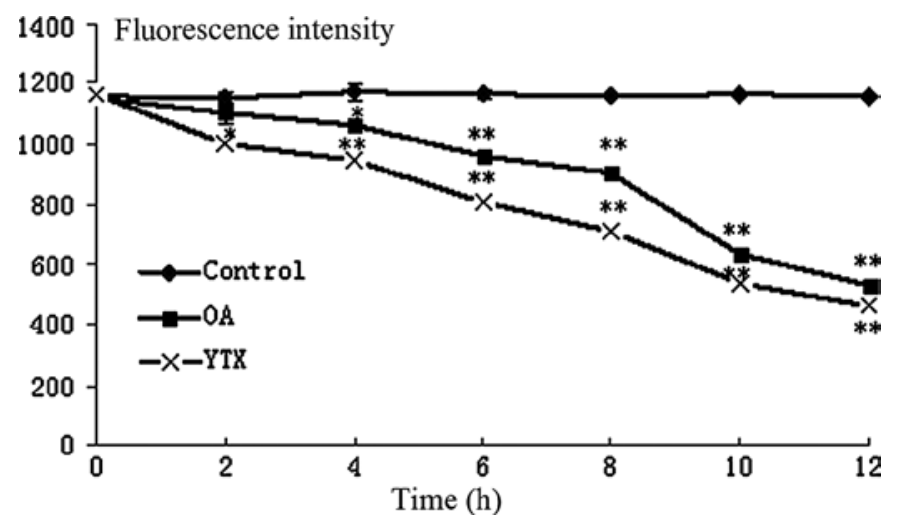

Figure 7. The mitochondrial transmembrane potential of Bel7402 cells treated with OA or YTX changed over the course of treatment in terms of fluorescence intensity after Rh123 staining. ${ }^{*} \mathrm{P}<0.05$ with respect to the control; ${ }^{* *} \mathrm{P}<0.01$.

Effects of toxins on mitochondrial transmembrane potential. Disruption of MTP is one of the earlier intracellular events in cell apoptosis. When Bel7402 cells were treated with OA or YTX for various periods at $37^{\circ} \mathrm{C}$, a decrease in MTP was detected using flow cytometry after staining with Rh123. As shown in Fig. 7, MTP began to be reduced markedly after $2 \mathrm{~h}$ of incubation with YTX. Over the course of treatment, MTP did not stop dropping until the end of incubation after $12 \mathrm{~h}$. Compared to OA, the influence of YTX on MTP occurred much stronger and earlier.

Effects of toxins on intracellular calcium levels. To investigate whether $\mathrm{Ca}^{2+}$ concentrations were changed in toxin-treated apoptotic human hepatoma cells, the average fluorescence intensity of intracellular $\mathrm{Ca}^{2+}$ was detected using flow cytometry after incubation with Fluo-3 AM. The results showed that the fluorescence intensity of the control and OA-treated groups changed only a little within $1 \mathrm{~h}$, while YTX enhanced the intracellular $\mathrm{Ca}^{2+}$ concentration significantly in Bel7402 cells (Fig. 8).

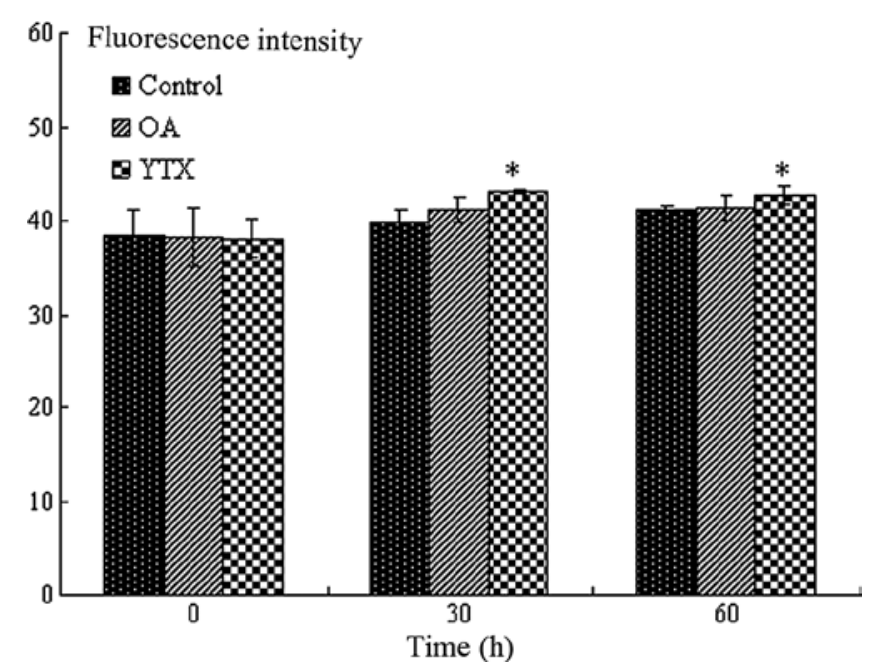

Figure 8. The intracellular $\mathrm{Ca}^{2+}$ concentration was evaluated in Bel7402 cells after treatment with $50 \mathrm{ng} / \mathrm{ml} \mathrm{OA}$ or $50 \mathrm{ng} / \mathrm{ml} \mathrm{YTX.} \mathrm{Changes} \mathrm{in} \mathrm{fluo-}$ rescence intensity detected by Fluo-3 AM staining were observed. ${ }^{*} \mathrm{P}<0.05$ with respect to the control.

\section{Discussion}

This study revealed that both OA and YTX are capable of inhibiting the growth of Bel7402 human hepatoma cells in a dose-dependent manner. A concentration over $100 \mathrm{ng} /$ $\mathrm{ml}$ was a strong cytotoxic dose against living cells. There are many reports on the cytotoxicity of YTX in various cell lines, including mammalian and insect cells (14-16,25). Using the Bel7402 human hepatoma cell line, we showed that YTX affects cell proliferation and induces apoptosis in a specific manner.

Apoptosis is a type of programmed cell death characterized by typical cellular and molecular features such as cell shrinkage, the condensation of chromatin and the externalization of phosphatidylserine (26). Compounds that induce apoptosis are considered to have anticancer activity (27), and many efforts have been made to discover novel anticancer drugs through the isolation of apoptosis, including agents from natural products.

Our study revealed that YTX triggers apoptosis in Bel7402 human hepatoma cells accompanied by morphological changes, DNA fragmentation, activation of caspase-3 and the loss of MTP.

After incubation with YTX, cell morphology showed characteristics typical of apoptosis, including cell shrinkage, nuclear fragmentation and chromatin condensation. Hoechst 33342 staining was used to observe nuclear changes in the apoptotic cells. Hoechst stains are a type of fluorescent stain used for labeling DNA in fluorescence microscopy and fluorescentactivated cell sorting (FACS), and can be used on live or fixed cells. Since Hoechst 33342 binds to DNA, it disrupts DNA replication during cell division (28). After staining cells with Hoechst 33342, the morphological changes of early-stage apoptosis were observable, including chromatin condensation and nuclear fragmentation into masses. Agarose gel electrophoresis also showed that both YTX and OA caused the 'ladder' pattern of DNA fragmentation in Bel7402 cells. Genomic DNA fragmentation is the biochemical hallmark of apoptosis. Due to the activation of special nuclear endonuclease, DNA in 
apoptotic cells is selectively cleaved at sites located between the nucleosome units and generates mono- and oligo-nucleomosal DNA fragments (29-31).

Caspases, a family of intracellular cysteine protease, are pivotal in the initiation and execution of apoptosis (32). Activation of caspases is one of the key elements in the apoptotic pathway. YTX is a sulfated polyether compound that may activate caspases during apoptosis. Our analysis showed the elevation of caspase-3 activities in Bel7402 cells treated with YTX. Activation of caspase-3 may cleave cytoskeletal and nuclear proteins, thus accelerating apoptosis in cells.

Mitochondria also play an important role in cellular metabolism, death signal transmission, caspase activation and other programmed cell death events. During apoptosis, mitochondrial permeability is altered and specific apoptotic protease activators are released from the mitochondria. The disruption of MTP is a crucial mechanism of apoptosis (33), and often precedes nuclear DNA fragmentation in most models of apoptosis (34-37). In our study, YTX decreased MTP, thus the loss of MTP may be involved in YTX-induced apoptosis. The disruption of MTP is associated with several factors, such as an increase in reactive oxygen species production and the elevation of $\mathrm{Ca}^{2+}$ concentration (38). $\mathrm{Ca}^{2+}$ is a sensor of programmed cell death that plays a crucial role in apoptotic signal transduction. Its overload leads to cellular damage and eventually cell death (39). For example, the activation of endonuclease, which cleaves DNA during apoptosis, is $\mathrm{Ca}^{2+}$ - and $\mathrm{Mg}^{2+}$-dependent (40). It has been reported that YTX induces the accumulation of $\mathrm{Ca}^{2+}$ in cells, and our study showed similar results; YTX increased the intracellular $\mathrm{Ca}^{2+}$ concentration.

The results of this study showed that YTX induced apoptosis in human hepatoma cells. The main reason may be the accumulation of $\mathrm{Ca}^{2+}$ induced by YTX, which disrupted MTP in human hepatoma cells, activated the endonuclease to cleave DNA, and then triggered apoptosis in the cells.

Our future studies will further examine the exact mechanisms of YTX-induced apoptosis to determine whether YTX has anticancer activity.

\section{Acknowledgements}

This study was supported by the International Cooperation Program of the Ministry of Science and Technology of the People's Republic of China (no. 2007DFA30710).

\section{References}

1. Yasumoto $\mathrm{T}$ and Takizawa A: Fluorometric measurement of yessotoxins in shellfish by high-pressure liquid chromatography. Biosci Biotechnol Biochem 61: 1775-1777, 1997.

2. EC: Commission Decision 2002/225/EC of 15 March 2002 laying down detailed rules for the implementation of Council Directive 91/492/EEC as regards the maximum levels and the methods of analysis of certain marine biotoxins in bivalve molluscs, echinoderms, tunicates and marine gastropods. Official Journal of the European Communities: 62, 2002.

3. Murata M, Masanori K, Lee JS and Yasumoto T: Isolation and structure of yessotoxin, a novel polyether compound implicated in diarrhetic shellfish poisoning. Tetrahedron Lett 28: 5869-5872, 1987.

4. Satake M, MacKenzie L and Yasumoto T: Identification of Protoceratium reticulatum as the biogenetic origin of yessotoxin. Nat Toxins 5: 164-167, 1997.
5. Tubaro A, Sidari L, Della LR and Yasumoto T: Occurrence of homoyessotoxin in phytoplankton and mussels from Northern Adriatic Sea. In: Harmful Algae. Reguera B, Blanco J, Fernández ML and Wyatt $\mathrm{T}$ (eds). Xunta de Galicia and Intergovernmental Oceanographic Commission of UNESCO, Grafisant, Santiago de Compostela, pp470-472, 1998.

6. Draisci R, Ferretti E, Palleschi L, Marchiafava C, Poletti R, Milandri A, Ceredi A and Pompei M: High levels of yessotoxin in mussels and presence of yessotoxin and homoyessotoxin in dinoflagellates of the Adriatic Sea. Toxicon 37: 1187-1193, 1999.

7. Stobo LA, Lewis J, Quilliam M A, Hardstaff WR, Gallacher S, Webster L, Smith E and McKenzie M: Detection of yessotoxin in UK and Canadian isolates of phytoplankton and optimization and validation of LC-MS methods. In: Proceedings of the Eighth Canadian Workshop on Harmful Marine Algae. Bates S (ed). Gulf Fisheries Centre, Moncton, New Brunswick, Canada, pp8-14, 2003.

8. Ciminiello P, Dell'Aversano C, Fattorusso E, Forino M, Magno S, Guerrini F, Pistocchi R and Boni L: Complex yessotoxins profile in Protoceratium reticulatum from northwestern Adriatic sea revealed by LC-MS analysis. Toxicon 42: 7-14, 2003.

9. Arévalo F, Pazos Y, Correa J, Salgado C, Moroño A, Paz B and Franco JM: First report of yessotoxins in mussels of Galician Rías during a bloom of Lingulodinium polyedra Stein (Dodge). In: Henshilwood K, Deegan B, McMahon T, Cusack C, Keaveney S, Silke J, O'Cinneide M, Lyons D and Hess P (eds). Galway, Ireland, pp184-189, 2006.

10. Morton SL, Vershinin A, Leighfield TA, Smith L and Quilliam M: Identification of yessotoxin in mussels from the Caucasian Black Sea Coast of the Russian Federation. Toxicon 50: 581-584, 2007.

11. Pan J, Li RX, Li Y and Sun P: Distribution of Dinoflagellate cysts in surface sediments from the southern Yellow Sea in autumn. Advence in Marine Science 28: 41-49, 2010.

12. Gao CL, Liu RY, Liang YB, Liu YJ, Pang M, Zhang F, Pan N, $\mathrm{Xu}$ DY and Shao KS: First report of the presence of yessotoxins (YTXs) in shellfish from China's coastal areas. Acta Oceanol Sin 3: 129-137, 2010.

13. De la Rosa LA, Alfonso A, Vilarino N, Vieytes MR and Botana LM: Modulation of cytosolic calcium levels of human lymphocytes by yessotoxin, a novel marine phycotoxin. Biochem Pharmacol 61: 827-833, 2001

14. Malagutia C, Ciminiellob P, Fattorussob E and Rossinia GP: Caspase activation and death induced by yessotoxin in HeLa cells. Toxicol in Vitro 16: 357-363, 2002.

15. Leira F, Alvarez C, Vieites JM, Vieytes MR and Botana LM: Characterization of distinct apoptotic changes induced by okadaic acid and yessotoxin in the BE (2)-M17 neuroblastoma cell line. Toxicol in Vitro 16: 23-31, 2002.

16. Korsnes MS, Hetland DL, Espenes A, Tranulis MA and Aune T: Apoptotic events induced by yessotoxin in myoblast cell lines from rat and mouse. Toxicol in Vitro 20: 1077-1087, 2006.

17. Green DR and Reed JC: Mitochondria and apoptosis. Science 281: 1308-1312, 1998.

18. Kroemer G: Introduction: mitochondrial control of apoptosis. Biochimie 84: 103-104, 2002.

19. Green DR and Kroemer G: The pathophysiology of mitochondrial cell death. Science 305: 626-629, 2004.

20. Hengartner MO: The biochemistry of apoptosis. Nature 407: $770-776,2000$

21. Kaufmann SH and Hengartner MO: Programmed cell death: alive and well in the new millennium. Trends Cell Biol 11: 526-534, 2001.

22. Thompson CB: Apoptosis in the pathogenesis and treatment of disease. Science 267: 1456-1462, 1995.

23. Kerr JFR, Wyllie AH and Currie AR: Apoptosis: a basic biological phenomenon with wideranging implications in tissue kinetics. Br J Cancer 26: 239-257, 1972.

24. Mosmann T: Rapid colorimetric assay for cellular growth and survival: application to proliferation and cytotoxicity assays. J Immunol Methods 65: 55-63, 1983.

25. Malagoli D, Marchesini E and Ottaviani E: Lysosomes as the target of yessotoxin in invertebrate and vertebrate cell lines. Toxicol Lett 167: 75-83, 2006.

26. Martin SJ, Reutelingsperger CP, McGahon AJ, Rader JA, van Schie RC, LaFace DM and Green DR: Early redistribution of plasma membrane phosphatidylserineis a general feature of apoptosis regardless of the initiating stimulus: inhibition by overexpression of Bcl-2 and Abl. J Exp Med 182: 1545-1556, 1995. 
27. Fankfurt OS and Krishan FA: Apoptosis-based drug screening and detection of selective toxicity to cancer cells. Anticancer Drug 14: 555-561, 2003.

28. Telford WG, Komoriya A and Packard BZ: Multiparametrci analysis of apoptosis by flow and image cytometry. In: Flow Cytometry Protocols (Methods in Molecular Biology). Hawley TS and Hawley RG (eds). Humana Press, USA, pp141-160, 2004.

29. Williams JR, Little JB and Shipley WU: Association of mammalian cell death with specific endonucleolytic degradation of DNA. Nature 252: 754-756, 1974

30. Wyllie AH: Glucocorticoid-induced thymocyte apoptosis is associated with endogenous endonuclease activation. Nature 284 : $555-556,1980$

31. Tilly JL: Use of the terminal transferase DNA labeling reaction for the biochemical and in situ analysis of apoptosis. In: Cell Biology: A Laboratory Handbook. Celis JE (ed). Academic Press, San Diego, pp330-337, 1994.

32. Thornberry NA and Lazebnik Y: Caspases: enemies within. Science 281: 1312-1316, 1998.

33. Lemasters JJ, Nieminen AL, Qian T, Trost LC, Elmore SP, Nishimura Y, Crowe RA, Cascio WE, Bradham CA, Brenner DA and Herman B: The mitochondrial permeability transition in cell death: a common mechanism in necrosis, apoptosis and autophagy. BBA-Bioenergetics 1366: 177-196, 1998.

34. Cossarizza A, Franceschi C, Monti D, Salvioli S, Bellesia E, Rivabene R, Biondo L, Rainaldi G, Tinari A and Malorni W: Protective effect of $\mathrm{N}$-acetylcysteine in tumor necrosis factoralphainduced apoptosis in U937 cells: the role of mitochondria. Exp Cel Res 220: 232, 1995.
35. Petit PX, Lecoeur H, Zorn E, Dauguet C, Mignotte B and Gougeon ML: Alterations of mitochondrial structure and function are early events of dexamethasone-induced thymocyte apoptosis. J Cell Biol 130: 157, 1995.

36. Zamzami N, Marchetti P, Castedo M, Decaudin D, Macho A, Hirsch T, Susin SA, Petit PX, Mignotte B and Kroemer G: Sequential reduction of mitochondrial transmembrane potential and generation of reactive oxygen species in early programmed cell death. J Exp Med 182: 367, 1995

37. Marchetti P, Susin SA, Decaudin D, Gamen S, Castedo M, Hirsch T, Zamzami N, Naval J, Senik A and Kroemer G: Apoptosis associated derangement of mitochondrial function in cells lacking mitochondrial DNA. Cancer Res 56: 2033, 1996.

38. Macho A, Hirsch T, Marzo I, Marchetti P, Dallaporta B, Susin SA, Zamzami N and Kroemer G: Glutathione depletion is an early and calcium elevation is a late event of thymocyte apoptosis. J Immunol 158: 4612-4619, 1997.

39. Smaili SS, Hsu YT, Carvalho ACP, Rosenstock TR, Sharpe JC and Youle RJ: Mitochondria, calcium and pro-apoptotic proteins as mediators in cell death signaling. Braz J Med Biol Res 36: 183-190, 2003.

40. McConkey DJ and Orrenius S: The role of calcium in the regulation of apoptosis. Biochem Bioph Res Co 239: 357-366, 1997. 